\title{
Reassessment of causes of ozone column variability following the eruption of Mount Pinatubo using a nudged CCM
}

\author{
P. Telford ${ }^{1}$, P. Braesicke ${ }^{1}$, O. Morgenstern ${ }^{1,2}$, and J. Pyle ${ }^{1}$ \\ ${ }^{1}$ NCAS-Chemistry-Climate, University of Cambridge, Cambridge, UK \\ ${ }^{2}$ now at: National Institute of Water and Atmospheric Research, Private Bag 50061, Omakau, \\ Central Otago 9352, New Zealand
}

Received: 9 February 2009 - Published in Atmos. Chem. Phys. Discuss.: 2 March 2009

Revised: 22 June 2009 - Accepted: 24 June 2009 - Published: 3 July 2009

\begin{abstract}
The eruption of Mount Pinatubo produced the largest loading of stratospheric sulphate aerosol in the twentieth century. This heated the tropical lower stratosphere, affecting stratospheric circulation, and provided enhanced surface area for heterogeneous chemistry. These factors combined to produce record low values of "global" total ozone column. Though well studied, there remains some uncertainty about the attribution of this low ozone, with contributions from both chemical and dynamical effects. We take a complementary approach to previous studies, nudging the potential temperature and horizontal winds in the new UKCA chemistry climate model to reproduce the atmospheric response and assess the impact on global total ozone. We then combine model runs and observations to distinguish between chemical and dynamical effects. To estimate the effects of increased heterogeneous chemistry on ozone we compare runs with volcanically enhanced and background surface aerosol density. The modelled depletion of global ozone peaks at about 7 DU in early 1993, in good agreement with values obtained from observations. We subtract the modelled aerosol induced ozone loss from the observed ozone record and attribute the remaining variability to 'dynamical' effects. The remaining variability is dominated by the QBO. We also examine tropical and mid-latitude ozone, diagnosing contributions from El Niño in the tropics and identifying dynamically driven low ozone in northern mid-latitudes, which we interpret as possible evidence of changes in the QBO. We conclude that, on a global scale, the record lows of extra-polar ozone are produced by the increased heterogeneous chemistry, although there is evidence for dynamics produced low ozone in certain regions, including northern mid-latitudes.
\end{abstract}

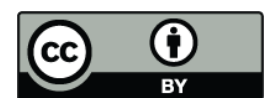

Correspondence to: P. Telford (paul.telford@atm.ch.cam.ac.uk)

\section{Introduction}

The eruption of Mount Pinatubo injected $20 \mathrm{Tg}$ of $\mathrm{SO}_{2}$ into the stratosphere which was, on the time-scales of weeks, converted into sulphate aerosol. At the time of maximum aerosol loading there was $30 \mathrm{Tg}$ of sulphate aerosol in the stratosphere (Bluth et al., 1992), the highest loading in the twentieth century (Robock, 2000). Following the eruption low values of ozone were observed in the lower stratosphere, particularly in winter and spring (Gleason et al., 1993; Hofmann et al., 1994; McGee et al., 1994; Randel et al., 1995). Angell (1997) calculated reductions in the total ozone column ranging from $2 \%$ in the tropics to $7 \%$ in mid-latitudes. Ozone depletion in the aerosol cloud was higher, locally reaching around 20\% (Grant, 1992, 1996).

Two processes involving the aerosol are implicated in the ozone reduction. The direct chemical effect was a result of the aerosol surface acting as sites for heterogeneous chemical reactions (Solomon, 1999). This locked $\mathrm{NO}_{\mathrm{x}}$ into inactive $\mathrm{HNO}_{3}$, liberating chlorine from reservoirs to active species, enabling the catalytic destruction of ozone (Fahey et al., 1993; Solomon, 1999; Robock, 2000). There was also an indirect effect as a result of the aerosol altering the temperature and dynamics of the stratosphere by absorbing radiation, heating the lower stratosphere. The temperature increases in the lower and middle stratosphere were significant, with peak increases at $30 \mathrm{hPa}$ of around $3.5 \mathrm{~K}$ (Labitzke and McCormick, 1992). This positive anomaly gradually decreased over the course of 1992 as the tropical aerosol was dispersed (McCormick et al., 1995). The heating of the stratosphere also caused increased tropical up-welling, raising air from regions with low ozone, reducing the ozone column (McCormick et al., 1995). The associated subsidence at high latitudes brought ozone down, potentially masking some of the destruction by chemical processes (Robock, 2000).

Published by Copernicus Publications on behalf of the European Geosciences Union. 
The ozone column in the Pinatubo period was also influenced by the phase of the Quasi-Biennial Oscillation (QBO) and the phase of the El Niño Southern Oscillation (ENSO). The QBO is a downward propagating variation of tropical zonal winds with a varying periodicity of around 28 months. It modulates the tropical up-welling and extra-tropical wave propagation, both affecting ozone concentrations (Baldwin et al., 2001). The heating of the lower stratosphere by the aerosols produced by Pinatubo affected the QBO, "locking" the phase of the QBO for several months (Thomas et al., 2009b). The years 1991 and 1992 had pronounced El Niño conditions as indicated by the multivariate ENSO index (Wolter and Timlin, 1993). El Niño affects tropical ozone, by changing circulation patterns and cooling the stratosphere. Much of the variation relates to changes in longitudinal patterns in ozone column and is removed by considering zonal means, but there is a residual variation in the tropical UTLS (Shiotani and Hasebe, 1994; Logan et al., 2003; Zeng and Pyle, 2005; Pyle et al., 2005). In the extra-tropics Randel and Cobb (1994) note some variation but confined to the Pacific and Shibata and Deushi (2008) model variability through the vertical profiles, though much seems to cancel when ozone columns are considered. One further factor contributing to changes in mid-latitude ozone is the variation in the export ozone depleted air from the polar vortex (Harris et al., 2008).

The large perturbation to the Earth's climate produced by the eruption has been the subject of many model studies, either focussing on the period itself (Bekki and Pyle, 1994; Rosenfield et al., 1997; Al-Saadi et al., 2001; Thomas et al., 2009a,b) or as part of simulations of recent ozone variations (Chipperfield, 1999; Dameris et al., 2005; Stolarski et al., 2006; Fleming et al., 2007; Mader et al., 2007; Wohltmann et al., 2007; Shibata and Deushi, 2008). Detailed studies of the ozone chemistry around the time of Pinatubo (Solomon et al., 1996; Rosenfield et al., 1997; Chipperfield, 1999) indicated that the main impact arose from the increase in aerosol surface area density. These studies modelled zonal mean depletion of $2-3 \%$ in mid latitudes, with larger depletion, up to $10 \%$, at higher latitudes in spring. Solomon et al. (1996) attributed this to changes in the $\mathrm{NO}_{\mathrm{x}} / \mathrm{NO}_{\mathrm{y}}$ abundance in the lower stratosphere enhancing the $\mathrm{ClO} / \mathrm{Cl}_{\mathrm{y}}$ ratio. They also noted that this depletion underestimated that observed by 50\%. Rosenfield et al. (1997) examined the impact of changes in aerosol heating rates on ozone columns. They diagnosed depletion in the tropics, around $2 \%$, immediately after the eruption with a small increase later in mid-latitudes. They also noted that changes in photolysis rates arising from increased optical depths had very little impact. In contrast the importance of dynamical effects was raised by Hadjinicolaou et al. (1997) who used a CTM forced by UKMO analyses throughout the 1990s. They ignored the chemical effects of the eruption, but their model still produced low ozone after the eruption. Their study considered only the northern midlatitudes.
The impacts of the eruption have also been considered in modelling studies of recent variability of ozone, with other factors studied including the QBO, Cl loading and solar variability (Dameris et al., 2005; Stolarski et al., 2006; Fleming et al., 2007; Shibata and Deushi, 2008). Stolarski et al. (2006) used a statistical model to determine the importance of these different terms in modelled and observed ozone. They showed that the eruption led to a peak reduction in global ozone ${ }^{1}$ of $6.7 \pm 1.1 \mathrm{DU}$, with the largest effect observed in the northern mid-latitudes. Their modelled response is smaller ( $4.0 \pm 1.1 \mathrm{DU})$ and predominantly in southern mid-latitudes. Fleming et al. (2007) note similar features, observing little effect in southern mid-latitudes in the data in contrast to significant modelled effects there. Dameris et al. (2005) looked at the impact of the eruption as part of a long term CCM study. They modelled a $20 \%$ increase in the vertical ascent rate leading to a $5 \%$ decrease in column ozone in the tropics.

Studies of the effects of Mt. Pinatubo have acquired new relevance after Crutzen (2006) and Wigley (2006) suggested that stratospheric sulphate aerosols could be used to mitigate global warming. Trenberth and Dai (2007) noted the disruption of the global hydrological cycle caused by the eruption. Tilmes et al. (2008) used a simple empirical method to look at the effect on polar ozone whilst Robock (2008) considered other widespread impacts on regional climate, the biosphere and ozone depletion and, in a more detailed study (Robock et al., 2008), predicted benefits to preserving arctic ice, but warned of possible disruptions to the African and Asian monsoons. Understanding the causes of ozone variability after the Pinatubo eruption could help inform judgements about the impacts of this form of geo-engineering.

Whilst the observation of low total ozone and the fact that the increased surface aerosol density caused ozone depletion are well established, the exact link of the observed low ozone to the increased surface aerosol density and other factors, such as dynamical variability, is still uncertain. Differing conclusions regarding the relative importance of chemistry and transport have been reached. It is important to resolve these uncertainties. For instance, as the concentrations of stratospheric halogens decrease, the impact on ozone of increased surface aerosol density, from volcanoes or geoengineering schemes is expected to decrease. However dynamical factors such as changes in stratospheric circulation, may still produce low ozone even with reduced halogen concentrations.

We use a new, complementary, approach to investigate the relative importance of different impacts of the eruption. This approach uses a nudged chemistry climate model (CCM) combining many of the best aspects of the existing CTM and CCMs. We use the information of the meteorological

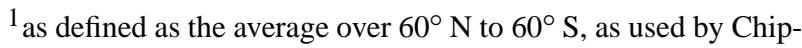
perfield et al. (2006) with high latitudes excluded due to unavailability of continuous ozone measurements during winter.
} 
analyses, as do CTMs, but in a framework with consistent model physics, including vertical wind as a prognostic variable in the CCM. The ability to reproduce the observed meteorology allows us to combine observations and model runs, with and without the increased surface aerosol density, to probe the different impacts of the eruption.

\section{Set up}

\subsection{Model}

We use a nudged version of the UKCA model (Telford et al., 2008). It is based upon the Met Office's Unified Model (MetUM), with the chemistry provided by the stratospheric version of UKCA (Morgenstern et al., 2008). This has a comprehensive stratospheric chemistry, including chlorine and bromine chemistry, and heterogeneous processing on polar stratospheric clouds (PSCs) and liquid sulfate aerosols. In addition it has a simplified tropospheric chemistry. Morgenstern et al. (2009) provide a detailed comparison of the CCM used in this study against a range of stratospheric composition data.

The configuration used here has

- a horizontal resolution of $3.75^{\circ} \times 2.5^{\circ}$ in longitude and latitude.

- 60 hybrid height levels in the vertical, from the surface up to a height of $84 \mathrm{~km}$.

- a dynamical time-step of $30 \mathrm{~min}$.

The sea surface temperatures and sea ice coverage are prescribed from the HadISST dataset (Rayner et al., 2003). The technique of nudging is used to reproduce the atmospheric conditions over the period studied. This constrains model horizontal winds and potential temperatures to ERA40 re-analysis data (Uppala et al., 2005). The nudging is applied from 3 to $45 \mathrm{~km}$ with a relaxation parameter of $\frac{1}{6} \mathrm{hr}^{-1}$ (Telford et al., 2008).

The solar flux is kept constant throughout the period. The chlorine and bromine loadings are kept constant at $3.4 \mathrm{ppbv}$ and $17.5 \mathrm{pptv}$ respectively. All species are initialised from a previous 10 year run of the model. The surface aerosol density (SAD) used to calculate heterogeneous chemical reactions is prescribed from a time dependent data-set created by D. Considine principally from the SAGE II instrument (Thomason et al., 1997), augmented by a small amount of data from the SAM II instrument (McCormick et al., 1979). The optical depth is prescribed from the data-set of Sato et al. (1993).

\subsection{Data}

The TOMS ${ }^{2} / \mathrm{SBUV}$ dataset provides the total ozone data from which we obtain information on variability during the 1990s (Bodeker et al., 2005). We attribute the causes of this variability by comparing to known drivers of variability, such as the QBO and ENSO. We use the zonal wind at $50 \mathrm{hPa}$ over Singapore as a proxy index for the QBO (Naujokat, 1986). Information about the phase of the ENSO is taken from the Multivariate Ensemble Index (MEI) of Wolter and Timlin (1993).

\subsection{Methodology}

Due to the limited coverage of the TOMS/SBUV data-set we exclude all data from latitudes polewards of $60^{\circ}$. Averaging the remaining data produces a quasi-global $\left(60^{\circ} \mathrm{N}\right.$ to $60^{\circ} \mathrm{S}$ ) total column ozone average, which we denote as "global ozone". In addition we average the total ozone column between $10^{\circ} \mathrm{N}$ to $10^{\circ} \mathrm{S}$ to obtain "tropical ozone" and between $30^{\circ}$ to $60^{\circ} \mathrm{S}$ and $\mathrm{N}$ to obtain southern and northern "mid-latitude ozone", respectively. We process these averages in a three stage process. First a linear trend is removed, then we account for the annual cycle by removing a sinusoidal best fit, before smoothing with a 6 month running average.

We performed three model runs (Table 1). Run A utilised all aspects of the model, nudging to ERA-40 and prescribing the SAD, to simulate the effects of the eruption. To isolate the impact of heterogeneous chemistry from the eruption Run B was made with the SAD fixed to 1990 values, which is taken to represent background levels. This run is intended to represent the situation without the Pinatubo aerosol, although it does include the associated dynamical changes from nudging. It is initialised from Run A at the start of January 1991. Run $\mathrm{C}$ was made without nudging, but with the increased, time varying, SAD, to investigate how well the free running model performs.

First, we compare the global total ozone data between Runs A, B and C to assess whether the runs provide a reasonable representation of the observed variability. We define the chemical effect of the eruption on ozone to be that caused by the changes in SAD after the eruption. This is evaluated from the differences in the ozone column between Runs A $\left(\mathrm{O}_{3}^{\mathrm{A}}\right)$ and $\mathrm{B}\left(\mathrm{O}_{3}^{\mathrm{B}}\right)$. Runs $\mathrm{A}$ and $\mathrm{B}$ are nudged to the same meteorological fields so that the difference in ozone between the two runs can be attributed to the change in SAD. This modelled chemical effect $\left(\Delta \mathrm{O}_{3}^{\text {chem }} \equiv \mathrm{O}_{3}^{\mathrm{A}}-\mathrm{O}_{3}^{\mathrm{B}}\right)$ is then subtracted from the observed ozone record $\left(\Delta \mathrm{O}_{3}^{\text {obs }}\right)$. The remaining ozone residual $\left(\Delta \mathrm{O}_{3}^{\text {dyn }} \equiv \Delta \mathrm{O}_{3}^{\text {obs }}-\Delta \mathrm{O}_{3}^{\text {chem }}\right)$ should then correspond to the "dynamical" effect, including that from the eruption, if we have successfully removed the chemical effect. Of course the whole system is highly coupled and

\footnotetext{
${ }^{2}$ Obtained from http://jwocky.gsfc.nasa.gov
} 
Table 1. Summary of runs made in the model.

\begin{tabular}{lcc}
\hline Run name & Dynamics & Surface Aerosol \\
\hline Best Guess (A) & nudged (1988-1998) & "pinatubo" (1988-1998) \\
Background (B) & nudged (1991-1998) & background (1990) \\
Free (C) & free (1988-1998) & "pinatubo" (1988-1998) \\
\hline
\end{tabular}
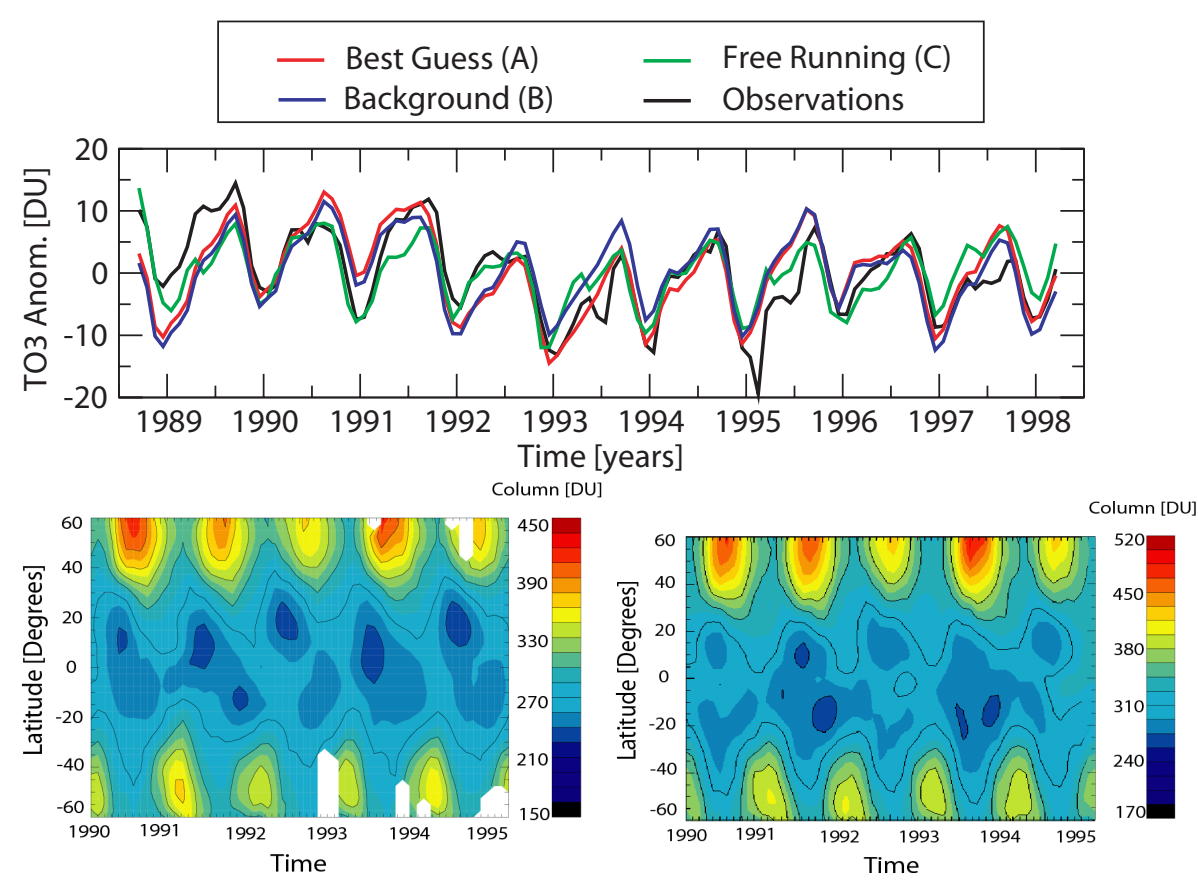

Fig. 1. Comparison of ozone column between model runs and TOMS/SBUV data. Top: Average global ozone column anomaly as a function of time in the data and in the three model runs. Bottom: zonal mean ozone column as a function of time in TOMS/SBUV data (left) and Run A, the best guess run (right). The model has been scaled to allow the spatial distributions to be compared.

dynamical and chemical processes interact through radiative transfer; our "dynamical" signal will include several factors. We repeat the procedure for tropical and northern and southern mid-latitude ozone.

\section{Results}

First we compare the global average ozone column between the model runs and the unprocessed data to assess the model's ability to reproduce the observed variability. We proceed to apply the methods described in Sect. 2.3 to distinguish chemical and dynamical effects for global (Sect. 3.2), tropical (Sect. 3.3) and mid-latitude ozone (Sect. 3.4).

\subsection{Validation of UKCA global ozone column}

Figure 1 shows the global average ozone column in the data and the model runs. For consistency the model ozone is treated identically to the data, with latitudes polewards of $60^{\circ}$ being excluded. As the global average ozone column in all model runs shows a slight high bias of around $10 \%$, we compare deviations from the mean rather than average values.

The combination of meteorology nudged towards reanalysis data and a simple prescription of increased surface aerosol density used in Run A produces a good representation of global ozone variability. Given that TOMS/SBUV ozone data are used in the ERA-40 assimilation over this period (Dethof and Holm, 2004) this good correspondence may be expected even though we neglect other factors, such as changes in chlorine loading and solar UV flux. This may reflect that these factors do not vary much over this period (Eyring et al., 2006; Fleming et al., 2007), or simply that the factors included in our model suffice.

Run B, with background SAD values, is able to reproduce much of the observed variability. However, as expected, it overestimates ozone in the years immediately after the eruption. The free running model, Run $\mathrm{C}$, is also able to capture many of the features of the ozone 


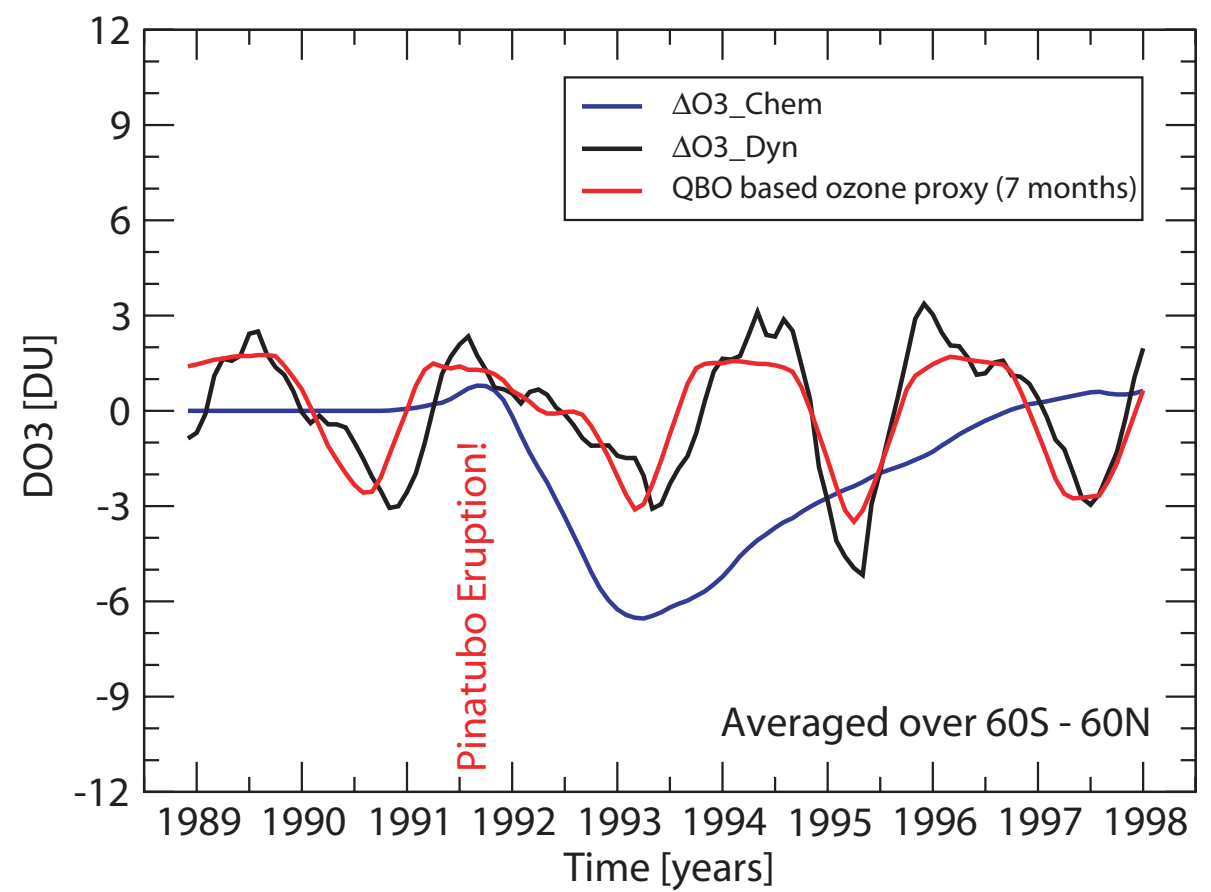

Fig. 2. Contribution to global ozone variability from chemical ( $\Delta \mathrm{O}_{3}^{\text {chem }}$, blue line) and from dynamical effects $\left(\Delta \mathrm{O}_{3}^{\text {dyn }}\right.$, black line). The chemical effects are evaluated from the differences between the best guess run (Run A) and that with background SAD (Run B). The dynamical effects are evaluated by subtracting this difference from the observations. A regression of $\Delta \mathrm{O}_{3}^{\text {dyn }}$ to the $\mathrm{QBO}$ proxy, with a lag of 7 months, is superimposed for comparison (red line).

variability, with some decrease after the eruption and large ozone loss in 1994/1995. However there are periods, such as 1993 and 1997, where significant differences can be seen. One explanation for these discrepancies is that the phase and periodicity of the modelled QBO in the free running model do not match those observed (Morgenstern et al., 2009).

In addition Fig. 1 shows latitude-time plots for the data and Run A. The spatial variation is well reproduced by the model, though the small bias necessitates using a slightly different scale to show this clearly. The reduction in the Northern Hemisphere spring maximum in 1993 and 1995 can be clearly seen in both the data and Run A.

\subsection{Attribution of variability in global ozone}

We apply the method described in Sect. 2.3 to evaluate the chemical effect $\left(\Delta \mathrm{O}_{3}^{\text {chem }}\right)$ of the volcanic SAD and the residual, dynamical effect $\left(\Delta \mathrm{O}_{3}^{\text {dyn }}\right)$. These are plotted in Fig. 2. In addition we regress the residual ozone variability to our QBO proxy.

The chemical effect of the eruption is clear, with ozone depletion increasing as the sulphate cloud spreads. This loss peaks at 7.2 DU around the start of 1993, then decreases in magnitude as the sulphate is removed from the stratosphere. By fitting this variation using linear trends we note that the initial ozone depletion was at a rate of $5.7 \pm 0.2$ DU/year with the recovery at a rate of $1.8 \pm 0.1 \mathrm{DU} / \mathrm{year}$. The magnitude and timing of the effect is in good agreement with that obtained by statistical methods, with Stolarski et al. (2006) determining the effect to peak in 1993 at $6.7 \pm 1.1 \mathrm{DU}$.

To consider our sensitivity to the prescribed SAD we have used an alternative data-set from the CCMVal project based on that compiled by SPARC (Thomason and Peter, 2006). This data-set has finer vertical and latitudinal resolution, and if the model is sensitive to the exact distribution of SAD could produce different values of total ozone. The magnitude of the ozone loss using this data-set is only $0.2 \mathrm{DU}$ smaller, indicating that with such large increases in SAD, its exact treatment is relatively unimportant, which may well explain why our coarsely gridded SAD data are able to reproduce the diagnosed ozone depletion. The timing is slightly different, with the rate of ozone recovery being slightly slower. The initial increase caused by heterogeneous chemistry shown in Fig. 2 is also less pronounced, which is attributed to the smaller vertical extent of the aerosol having a smaller impact on $\mathrm{NO}_{\mathrm{x}}$ chemistry.

We subtract the chemical effect $\left(\Delta \mathrm{O}_{3}^{\text {chem }}\right)$ from the observed variability as described in Sect. 2.3 to obtain the residual, dynamical effect $\left(\Delta \mathrm{O}_{3}^{\mathrm{dyn}}\right)$. This residual exhibits a quasi biennial variation. A regression of $\Delta \mathrm{O}_{3}^{\text {dyn }}$ to our QBO proxy, the $50 \mathrm{hPa}$ zonal wind at Singapore, with a lag of 7 months to account for time to propagate to the extra-tropics, 


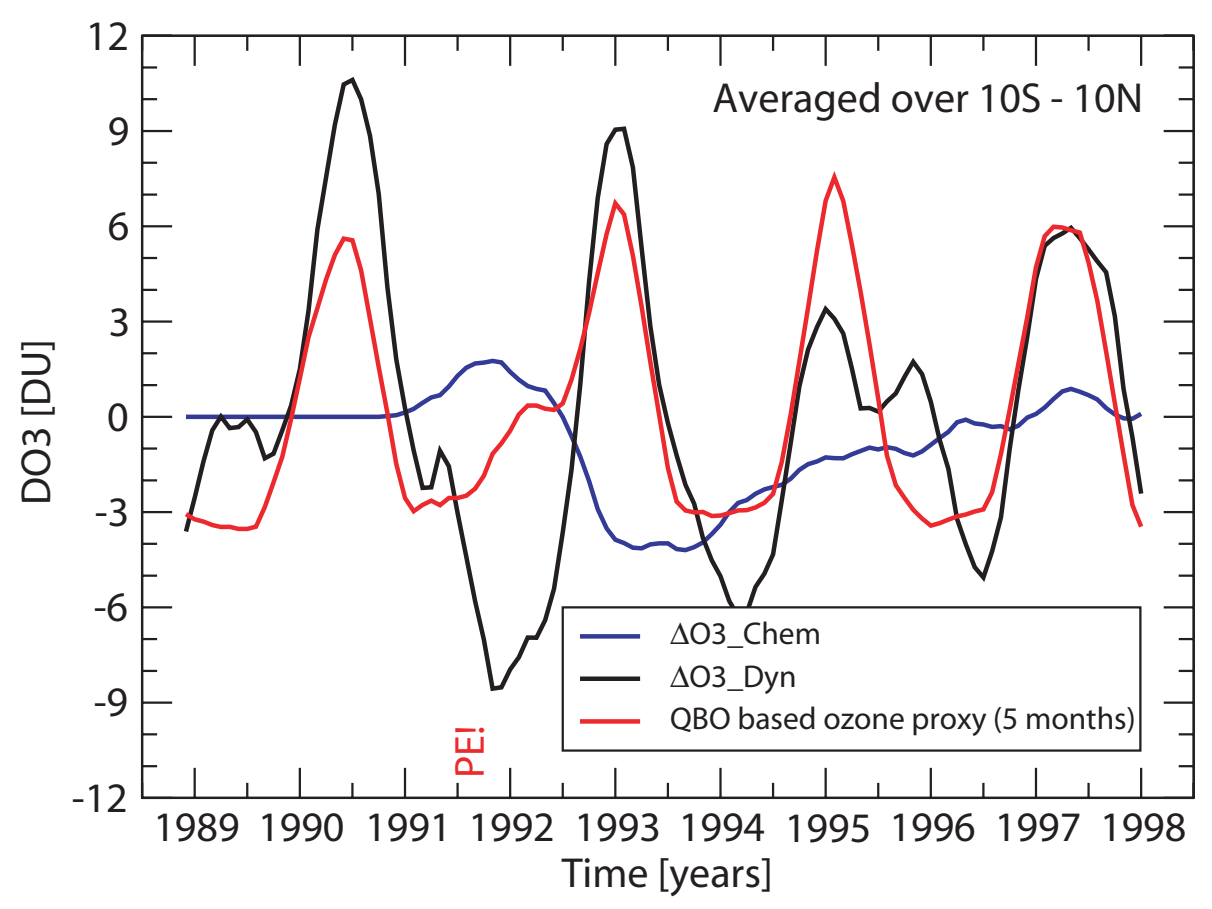

Fig. 3. Contribution to tropical $\left(10^{\circ} \mathrm{S}-10^{\circ} \mathrm{N}\right)$ variability from chemical $\left(\Delta \mathrm{O}_{3}^{\text {chem }}\right.$, blue line $)$ and from dynamical effects $\left(\Delta \mathrm{O}_{3}^{\text {dyn }}\right.$, black line). The chemical effects are evaluated from the differences between the best guess run (Run A) and that with background SAD (Run B). The dynamical effects are evaluated by subtracting this difference from the observations. A regression of $\Delta \mathrm{O}_{3}^{\text {dyn }}$ to the $\mathrm{QBO}$ proxy, with a lag of 5 months, is superimposed for comparison (red line). The timing of the Pinatubo eruption is marked by "PE".

is superimposed for comparison. The dynamical effect and our QBO proxy correlate well, with a correlation coefficient greater than 0.8. A similar correlation is obtained if a lag of 8 months rather than 7 is used. Evidently the remaining variability is attributable predominantly (more than 65\%) to the QBO. The presence of this correlation also increases our confidence in the reliability of the subtraction of the modelled chemical effect, as any residual chemical signal would be unlikely to correlate with the QBO. By using time lagged correlations we also conclude that there is no evidence that the ENSO has any large impact on the remaining variability.

In agreement with other studies we conclude that the main cause of the observed low global ozone after Pinatubo was the increased surface aerosol density. However dynamics determine the timing of the lowest values. In addition they may have a greater effect on regional scales. To investigate whether this is the case we examine three regions separately: the tropics and northern and southern mid-latitudes.

\subsection{Tropical ozone column}

The QBO is a tropical phenomenon. In light of the strong relationship between the global ozone and our QBO proxy it is interesting to see its role in the modelled tropical ozone column. So we repeat the procedure used to study the global ozone for the tropics. The resulting contributions from chemical and dynamical factors are shown in Fig. 3.
The contribution from the chemical effect is smaller, peaking at around $-3 \mathrm{DU}$, than in the global case, but the rates of change are similar, decreasing at $5.1 \pm 0.2 \mathrm{DU} / \mathrm{year}$ before recovering at $1.9 \pm 0.1$ DU/year.

As in the global case the residual, "dynamical", effect correlates well with our QBO proxy index, with a correlation coefficient greater than 0.8 . The lag used is different, and the proxy is inverted, which reflects the different influence the QBO has on tropical and global ozone. The period between 1991 and 1992 is the one period where the correlation is poorer, which corresponds to the warm phase of ENSO. To quantify this relationship we remove the variability of the $\mathrm{QBO}$ by subtracting the $\mathrm{QBO}$ based proxy from $\Delta \mathrm{O}_{3}^{\text {dyn }}$ and correlate the remaining variability with the ENSO proxy, producing a correlation coefficient of 0.45 , significant at the 95\% level. The ability to produce this correlation without a lag suggests a more immediate impact of ENSO on tropical ozone column. The lowest values occur in late 1991 and 1992, just after the eruption of Mt. Pinatubo, suggesting that dynamical changes from the eruption could contribute to the low ozone as well. The magnitude of any changes caused by the eruption are too small to quantify with our technique.

In the tropics the chemical depletion is smaller than the dynamical effect, which is still attributable to the QBO, although with a significant contribution from ENSO. We now investigate the mid-latitudes where both the chemical effects 

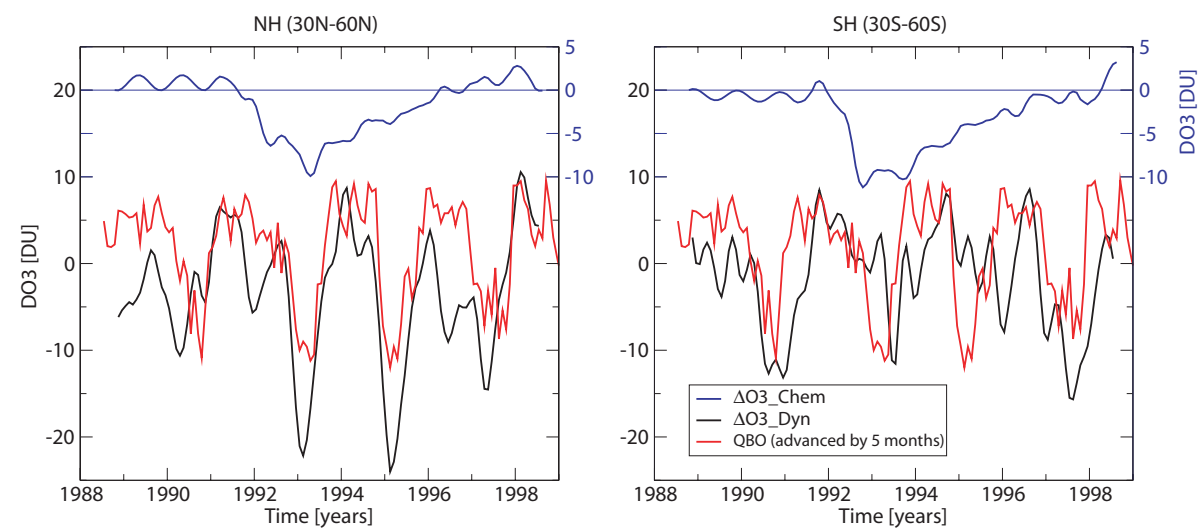

Fig. 4. Contribution to northern (left) and southern (right) mid-latitudes $\left(30^{\circ}-60^{\circ}\right)$ ozone variability from chemical $\left(\Delta \mathrm{O}_{3}^{\text {chem }}\right.$, blue line) and from dynamical effects ( $\Delta \mathrm{O}_{3}^{\text {dyn }}$, black line). The chemical effects are evaluated from the differences between the best guess run (Run A) and that with background SAD (Run B). The dynamical effects are evaluated by subtracting this difference from the observations. A regression of $\Delta \mathrm{O}_{3}^{\mathrm{dyn}}$ to the QBO proxy, with a lag of 5 months, is superimposed for comparison (red line).

are larger and where previous studies such as Hadjinicolaou et al. (1997) have argued for an important dynamical contribution to ozone variability.

\subsection{Mid-latitude ozone columns}

The mid-latitudes are the regions where large chemical ozone depletion (Chipperfield, 1999) and dynamically induced low ozone (Hadjinicolaou et al., 1997) have been modelled after the eruption. To investigate whether we see such effects we repeat the procedure used to study the global and tropical ozone for the northern and southern mid-latitudes. The resulting contributions from chemical and dynamical factors are shown in Fig. 4.

Ozone depletion due to increased aerosol surface is larger than that at lower latitudes, peaking around $10 \mathrm{DU}$ in both the Northern and Southern Hemispheres (Fig. 4). The variation of the depletion over time is less smooth, showing a large annual cycle, with the heterogeneous depletion peaking in spring. The magnitude of the depletion is similar in both hemispheres, in agreement with the studies of Fleming et al. (2007) and Stolarski et al. (2006). When we subtract the chemical effect from the observations to produce the "dynamical" effect we see differences between the northern and southern mid-latitudes. This is in agreement with the observed ozone variability, as seen by Bodeker et al. (2001), Stolarski et al. (2006) and Fleming et al. (2007), where lower ozone values were seen in northern midlatitudes.

In the Southern Hemisphere the amplitude of ozone interannual variability is constant throughout the period. We note that away from the eruption there appears to be some correlation with our QBO proxy, with none in the years immediately after the eruption. In the Northern Hemisphere the variability looks similar to that in the Southern in the early and later years. However in 1993 and 1995 we diagnose low ozone, which appears to correlate well with our QBO proxy.

This additional dynamically driven low ozone in the northern mid-latitudes can explain the discrepancy observed between the chemical impact and observations by Solomon et al. (1996) and others. Some of the variability can also be explained by changes in ozone loss due to high latitude PSCs subsequently exported to mid-latitudes, although this effect peaks later in the year than our "dynamical" effect (Harris et al., 2008). In northern mid-latitudes the dynamically induced low ozone is also considerable larger than the chemical depletion, in agreement with the results of Hadjinicolaou et al. (1997). Interestingly during the years after the eruption better correlation is obtained using a lag of 5 months, as opposed to 7 months in the other years, suggesting a qualitative difference in the relationship between the QBO and mid-latitude ozone after the eruption of Mt. Pinatubo. This may be due to impacts of the eruption on the QBO, such as phase-locking, as seen by Thomas et al. (2009b) and others.

\section{Conclusions}

We use the new UKCA CCM to study the ozone variability around the time of the eruption of Mount Pinatubo. We "nudge" the model to reproduce the observed dynamical effect and investigate the impacts of increased heterogeneous chemistry by comparing results of runs with and without increased surface aerosol density. We subtract the modelled ozone changes from the observed total ozone column record to obtain the impacts of the "dynamical" effect. The record low global ozone in 1993 is mainly a result of the increased heterogeneous chemistry, but augmented by some regional dynamical effects, most notably in northern mid-latitudes. 
The increased heterogeneous chemistry causes global ozone depletion, peaking at around 7 DU in early 1993, in good agreement with values obtained from observations. The global dynamical effect is smaller than the chemical depletion and, by comparing with a QBO proxy, can be attributed to being predominantly caused by the QBO. On global scales we see no evidence of contributions from ENSO or direct dynamical impacts of the eruption. In the tropics the chemical depletion is smaller than the dynamical effect, which is still attributable to the QBO, although with a significant contribution from ENSO.

In both northern and southern mid-latitudes the heterogeneous chemistry causes ozone depletion, peaking around $10 \mathrm{DU}$ in late 1992 and early 1993. In addition there is dynamical variability which correlates with the QBO, though this variation differs between the Northern and Southern Hemispheres. In the north the dynamical driven variability is greater, producing reductions in ozone columns even larger than the chemical depletion, in agreement with Hadjinicolaou et al. (1997). We speculate that this low ozone arises from qualitative differences in the QBO after the eruption, which will be interesting to study with a free running model using an ensemble approach. This study serves as a physical attribution test case for estimating ozone loss after major volcanic eruptions and at the same time validates the underlying $\mathrm{CCM}$ and its ability to capture ozone inter-annual variability.

Acknowledgements. This work was supported by NCAS. We also acknowledge support through the EU FP6 Integrated Programme, SCOUT-O3 (505390-GOCE-CT-2004). The ERA-40 data was obtained from the BADC. We thank David Considine for the development of the aerosol climatology.

Edited by: M. Dameris

\section{References}

Al-Saadi, J., Pierce, R., Fairlie, T., Kleb, M., Eckman, R., Grose, W., Natarajan, M., and Olson, J.: Response of middle atmosphere chemistry and dynamics to volcanically elevated sulfate aerosol: Three-dimensional coupled model simulations, J. Geophys. Res., 106, 27255-27275, 2001.

Angell, J.: Estimated impact of Agung, E1 Chichon, and Pinatubo volcanic eruptions on global and regional total ozone after adjustment for the QBO, Geophys. Res. Lett., 24, 647-650, 1997.

Baldwin, M., Gray, L., Dunkerton, T., Hamilton, K., Haynes, P., Randel, W., Holton, J., Alexander, M., Hirota, I., and Horinouchi, T.: The quasi biennial oscillation, Rev. Geophys., 39, 179-230, 2001.

Bekki, S. and Pyle, J.: A two dimensional modeling study of the volcanic eruption of Mount Pinatubo, J. Geophys. Res., 99, 18861-18869, 1994.

Bluth, G., Doiron, S., Schnetzler, C., Krueger, A., and Walter, L.: Global Tracking of the $\mathrm{SO}_{2}$ clouds from the June, 1991 MountPinatubo Eruptions, Geophys. Res. Lett., 19, 151-154, 1992.
Bodeker, G., Connor, B., Liley, J., and Matthews, W.: The global mass of ozone: 1978-1998, Geophys. Res. Lett., 28, 2819-2822, 2001.

Bodeker, G. E., Shiona, H., and Eskes, H.: Indicators of Antarctic ozone depletion, Atmos. Chem. Phys., 5, 2603-2615, 2005, http://www.atmos-chem-phys.net/5/2603/2005/.

Chipperfield, M.: Multiannual simulations with a three-dimensional chemical transport model, J. Geophys. Res., 104, 1781-1805, 1999.

Chipperfield, M., Fioletov, V., Bregman, B., Burrows, J., Connor, B., Haigh, J., Harris, N., Hauchecorne, A., Hood, L., Kawa, S., Krzyścin, J., Logan, J., Muthama, N., Polvani, L., Randel, W., Sasaki, T., Stähelin, J., Stolarski, R., Thomason, L., and Zawodny, J.: Global Ozone: Past and Present, chapter 3, World Meteorological Organisation, 3.1-3.58, 2006.

Crutzen, P.: Albedo enhancement by stratospheric sulfur injections: A contribution to resolve a policy dilemma?, Clim. Change, 77, 211-220, 2006.

Dameris, M., Grewe, V., Ponater, M., Deckert, R., Eyring, V., Mager, F., Matthes, S., Schnadt, C., Stenke, A., Steil, B., Brühl, C., and Giorgetta, M. A.: Long-term changes and variability in a transient simulation with a chemistry-climate model employing realistic forcing, Atmos. Chem. Phys., 5, 2121-2145, 2005, http://www.atmos-chem-phys.net/5/2121/2005/.

Dethof, A. and Holm, E.: Ozone assimilation in the ERA-40 reanalysis project, Q. J. Roy. Meteorol. Soc., 130, 2851-2872, 2004.

Eyring, V., Butchart, N., Waugh, D., Akiyoshi, H., Austin, J., Bekki, S., Bodeker, G., Boville, B., Brühl, C., Chipperfield, M., Cordero, E., Dameris, M., Deushi, M., Fioletov, V., Frith, S., Garcia, R., Gettelman, A., Giorgetta, A., Grewe, V., Jourdain, L., Kinnison, D., Mancini, E., Manzini, E., Marchand, M., Marsh, D., Nagashima, T., Newman, P., Nielsen, J., Pawson, S., Pitari, G., Plummer, D., Rozanov, E., Schraner, M., Shepherd, T., Shibata, K., Stolarski, R., Struthers, H., Tian, W., and Yoshiki, M.: Assessment of temperature, trace species, and ozone in chemistry-climate model simulations of the recent past, J. Geophys. Res., D22308, 111, doi:10.1029/2006JD007327, 2006.

Fahey, D., Kawa, S., Woodbridge, E., Tin, P., Wilson, J., Jonsson, H., Dye, J., Baumgardner, D., Borrmann, S., Toohey, D., Avallone, L., Proffitt, M., Margitan, J., Loewenstein, M., Podolske, J., Salawitch, R., Wofsy, S., Ko, M., Anderson, D., Schoeberl, M., and Chan, K.: In situ measurements constraining the role of sulfate aerosols in mid-latitude ozone depletion, Nature, 363, 509-514, 1993.

Fleming, E., Jackman, C., Weisenstein, D., and Ko, M.: The impact of interannual variability on mutidecadel total ozone simulations, J. Geophys. Res., 112, D10310, doi:10.1029/2006JD007953, 2007.

Gleason, J. and Bhartia, P. and Herman, J. and McPeters, R and Newman, P. and Stolarski, R. and Flynn, L. and Labow, G. and Larko, D. and Seftor, C. and Wellemeyer, C. and Komhyr, W. and Miller, A. and Planet, W.: Record low global ozone in 1992, Science, 260, 523-526, 1993.

Grant, W.: Observations of reduced ozone concentrations in the tropical atmosphere after the eruption of Mount Pinatubo, Geophys. Res. Lett., 19, 1109-1112, 1992.

Grant, W.: Tropical stratospheric ozone changes following the eruption of Mount Pinatubo, in: The Mount Pinatubo Eruption Effects on the Atmosphere and Climatem, edited by: Springer- 
Verlag, New York, USA, NATO ASI Set., Set. I, 42, 161-175, 1996.

Hadjinicolaou, P., Pyle, J., Chipperfield, M., and Kettleborough, J.: Effect of interannual meteorological variability on midlatitude O3, Geophys. Res. Lett., 24, 2993-2996, 1997.

Harris, N., Kyror, E., Staehelin, J., Brunner, D., Andersen, S., Godin-Beekmann, S., Dhomse,S., Hadjinicolaou, P., Hansen, G., Isaksen, I., Jrrar, A., Karpetchko,A., Kivi, R., Knudsen, B., Krizan, P, Lastovicka, J., Maeder, J., Orsolini, J., Pyle, J., Rex, M., Vanicek, K., Weber, M., Wohltmann, I., Zanis, P., and Zerefos, C.: Ozone trends at northern mid- and high latitudes a European perspective, Ann. Geophys., 26, 1207-1220, 2008, http://www.ann-geophys.net/26/1207/2008/.

Hofmann, D., Oltmans, S., Komhyr, W., Harris, J., Lathtop, J., Langford, A., Deshler, T., Johnson, B., Torres, A., and Matthews, W.: Ozone loss in the lower stratosphere over the United States in 1992-1993: Evidence for heterogeneous chemistry on the Pinatubo aerosols, Geophys. Res. Lett., 21, 65-68, 1994.

Labitzke, K. and McCormick, M.: Stratospheric temperature increases due to Pinatubo aerosols, Geophys. Res. Lett., 19, 207210, 1992.

Logan, J., Jones, D., Megretskaia, I., Oltmans, S., Johnson, B., Vömel, H., Randel, W., Kimani, W., and Schmidlin, F.: Quasibiennial oscillation in tropical ozone as revealed by ozonesonde and satellite data, J. Geophys. Res., 108(D8), doi:10.1029/2002JD002170, 4244, 2003.

Mäder, J. and Staehelin, J. and Brunner, D. and Stahel, W. and Wohltmann, I. and Peter,T.: Statistical Modelling of Total Ozone: Selection of approppriate explanatory variables, J. Geophys. Res., 112(D11), doi:10.1029/2006JD007694, 108, 2007.

McCormick, M., Hamill, P., Pepin, T., Chu, W., Swissler, T., and McMaster, L.: Satellite Studies of Stratospheric Aerosols, BAMS, 60, 1038-1046, 1979.

McCormick, M., Thomason, L., and Trepte, C.: Atmospheric Effects of the Mount Pinatubo Eruption, Nature, 373, 399-405, 1995.

McGee, T., Newman, P., Gross, M., Singh, U., Godin, S., Lacoste, A.-M., and Magie, G.: Correlation of ozone loss with the presence of volcanic aerosols, Geophys. Res. Lett., 21, 2801-2804, 1994.

Morgenstern, O., Braesicke, P., Hurwitz, M., O’Connor, F., Bushell, A., Johnson, C., and Pyle, J.: The World Avoided by the Montreal Protocol, Geophys. Res. Lett., 35, L16811, doi:10.1029/2008GL034590, 2008.

Morgenstern, O., Braesicke, P., O'Connor, F., Bushell, A., Johnson, C., Osprey, S., and Pyle, J.: Evaluation of the new UKCA climate-composition model. Part 1: The Stratosphere, GMD, 2, 43-57, 2008.

Naujokat, B.: An update of the observed quasi-biennial oscillation of the stratospheric winds over the tropics, J. Atmos. Sci., 43, 1873-1877, 1986.

Pyle, J., Braesicke, P., and Zeng, G.: Dynamical variability in the modeling of chemistry - climate interactions, Faraday Discuss., 130, 27-39, 2005.

Randel, W. and Cobb, J.: Coherent variations of monthly mean total ozone and lower stratospheric temperature, J. Geophys. Res., 99, 5433-5447, 1994.

Randel, W., Wu, F., Russell III, J., Waters, J., and Froidevaux, L.: Ozone and temperature changes in the stratosphere following the eruption of Mount Pinatubo, J. Geophys. Res., 100, $16753-$ 16764, 1995.

Rayner et al(2003) full reference: Rayner N. A., Parker, D. E., Horton, E. B., Folland, C. K., Alexander, L. V., Rowell, D. P., Kent, E. C., and Kaplan, A.: Global analyses of sea surface temperature, sea ice, and night marine air temperature since the late nineteenth century, J. Geophys. Res., 108(D14), 4407, doi:10.1029/2002JD002670, 2003.

Robock, A.: Volcanic eruptions and climate, Rev. Geophys., 38, 191-219, 2000.

Robock, A.: 20 reasons why geoengineering may be a bad idea, B. Am Meteor. Soc., 64, 14-59, 2008.

Robock, A., Oman, L., and Stenchikov, G.: Regional climate responses to geoengineering with tropical and Arctic $\mathrm{SO}_{2}$ injections, J. Geophys. Res., 113, D16101, doi:10.1029/2008JD010050, 2008.

Rosenfield, J., Considine, D., Meade, P., Bacmeister, J., Jackman, C., and Schoeberl, M.: Stratospheric effects of Mount Pinatubo aerosol studied with a coupled two dimensional model, J. Geophys. Res., 102, 3649-3670, 1997.

Sato, M., Hansen, J., McCormick, M., and Pollack, J.: Stratospheric Aerosol Opical Depths 1850-1990, J. Geophys. Res., 98, $22987-$ 22994, 1993

Shibata, K. and Deushi, M.: Long-term variations and trends in the simulation of the middle atmosphere 1980-2004 by the chemistry-climate model of the Meteorological Research Institute, Ann. Geophys., 26, 1299-1326, 2008, http://www.ann-geophys.net/26/1299/2008/.

Shiotani, M. and Hasebe, F.: Stratospheric ozone variations in the equatorial region as seen in Stratospheric Aerosol and Gas Experiment data, J. Geophys. Res., 99, 14575-14584, 1994.

Solomon, S.: Stratospheric ozone depletion: A review of concepts and history, Rev. Geophys., 37, 275-316, 1999.

Solomon, S., Portmann, R., Garcia, R., Thomason, L., Poole, L., and McCormick, M.: The role of aerosol variations in anthropogenic ozone depletion at northern midlatitudes, J. Geophys. Res., 101, 6713-6727, 1996.

Stolarski, R., Douglass, A., Steenrod, S., and Pawson, S.: Trends in Stratospheric Ozone: Lessons Learned from a 3D Chemical Transport Model, J. Atmos. Sci., 63, 1028-1042, 2006.

Telford, P., Braesicke, P., Morgenstern, O., and Pyle, J.: Technical Note: Description and assessment of a nudged version of the new dynamics Unified Model, Atmos. Chem. Phys., 8, 1701-1712, 2008, http://www.atmos-chem-phys.net/8/1701/2008/.

Thomas, M. A., Giorgetta, M. A., Timmreck, C., Graf, H.-F., and Stenchikov, G.: Simulation of the climate impact of Mt. Pinatubo eruption using ECHAM5 - Part 2: Sensitivity to the phase of the QBO, Atmos. Chem. Phys., 9, 3001-3009, 2009a, http://www.atmos-chem-phys.net/9/3001/2009/.

Thomas, M. A., Timmreck, C., Giorgetta, M. A., Graf, H.-F., and Stenchikov, G.: Simulation of the climate impact of Mt. Pinatubo eruption using ECHAM5 Part 1: Sensitivity to the modes of atmospheric circulation and boundary conditions, Atmos. Chem. Phys., 9, 757-769, 2009b, http://www.atmos-chem-phys.net/9/757/2009/.

Thomason, L. and Peter, T.: Assessment of Stratospheric Aerosol Properties, Tech. Rep. WMO-TD No. 1295, WCRP Series Report No. 124, SPARC Report No. 4, Berrieres le Buisson Cedex, 2006. 
Thomason, L., Poole, L., and Deshler, T.: A global climatology of stratospheric aerosol surface area density deduced from Stratospheric Aerosol and Gas Experiment II measurements 19841994, J. Geophys. Res., 102, 8967-8976, 1997.

Tilmes, S., Müller, R., and Salawitch, R.: The Sensitivity of Polar Ozone Depletion to Proposed Geoengineering Schemes, Science, 320, 1201-1204, 2008.

Trenberth, K. and Dai, A.: Effects of Mount Pinatubo volcanic eruption on the hydrological cycle as an ana$\log$ of geoengineering, Geophys. Res. Lett., 34, 15702, doi:10.1029/2007GL030524, 2007.

Uppala, S., Kallberg, P., Simmons, A., Andrae, U., Da Costa Bechtold, V., Fiorino, M., Gibson, J., Haseler, J., Hernandez, A., Kelly, G., Li, X., Onogi, K., Saarinen, S., Sokka, N., Allan, R., Andersson, E., Arpe, K., Balmaseda, M., Beljaars, A., van de Berg, L., Bidlot, J., Bormann, N., Caires, S., Chevallier, F., Dethof, A., Dragosavac, M., Fisher, M., Fuentes, M., Hagemann, S., Holm, E., Hoskins, B., Isaksen, L., Janssen, P., Jenne, R., McNally, A., Mahfouf, J.-F., Morcrette, J.-J., Rayner, N., Saunders, R., Simon, P., Sterl, A., Trenberth, K., Untch, A., Vasiljevic, D., Viterbo, P., and Woollen, J.: The ERA-40 re-analysis, Q. J. Roy. Meteor. Soc., 131, 2961-3012, 2005.
Wigley, T.: A combined mitigation/geoengineering approach to climate stabilization, Science, 314, 452-454, doi:10.1126/science.1131728, 2006.

Wohltmann, I., Lehmann, R., Rex, M., Brunner, D., and Mäder, J.:A process-orientated regression model for column ozone , J. Geophys. Res., 112(D12), doi:10.1029/2006JD007573, 306, 2007.

Wolter, K. and Timlin, M.: Monitoring ENSO in COADS with a seasonally adjusted principal component index, in: Proc. of the 17th Climate Diagnostics Workshop, Norman, OK, NOAA/N MC/CAC, NSSL, Oklahoma Clim. Survey, CIMMS and the School of Meteor., Univ. of Oklahoma, online available at: http: //www.cdc.noaa.gov/people/klaus.wolter/MEI/, 52-57, 1993.

Zeng, G. and Pyle, J.: Influence of El Niño Southern Oscillation on stratosphere/troposphere exchange and the global tropospheric ozone budget, Geophys. Res. Lett., 32, L01814, doi:10.1029/2004GL021353, 2005. 